\title{
APLIKASI ANDROID 'SMART TECHNICAL ENGLISH' UNTUK MENINGKATKAN KEAHLIAN BAHASA INGGRIS MAHASISWA VOKASI
}

\author{
Dian Asa Utari ${ }^{1}$, Miftachudin ${ }^{2}$, Muhammad Khoirul Hasin ${ }^{3}$ \\ ${ }^{1}$ Design and Manufacture Engineering, Shipbuilding Institute of Polytechnic Surabaya, \\ Surabaya, Indonesia \\ ${ }^{2}$ Marine Engineering, Shipbuilding Institute of Polytechnic Surabaya, Surabaya, Indonesia \\ ${ }^{3}$ Automation Engineering Study Program, Shipbuilding Institute of Polytechnic Surabaya, \\ Surabaya, Indonesia \\ E-Mail: dian.asa.utari@ppns.ac.id,miftachudin@ppns.ac.id
}

\begin{abstract}
Abstrak
Di era global saat ini lulusan politeknik harus bersaing semakin ketat dengan semakin banyak pekerja asing yang memiliki kemampuan komunikasi yang unggul. Agar lebih unggul, lulusan politeknik wajib menguasai bahasa asing internasional yaitu Bahasa Inggris sebagai persiapan mereka memasuki dunia kerja. Namun pada kenyataannya, skill Bahasa Inggris yang dimiliki oleh mahasiswa politeknik masih kurang, terutama dalam keterampilan berbicara (speaking) dan menulis (writing). Beberapa faktor yang berpengaruh dalam peningkatan kemampuan Bahasa Inggris di pendidikan vokasi adalah metode pembelajaran yang interaktif dan penggunaan teknologi yang tepat untuk memotivasi mahasiswa dalam belajar Bahasa Inggris. Oleh karena itu peneliti ingin mengembangkan aplikasi 'Technical English' berbasis Android yang telah ada dengan menambahkan fitur listening, writing dan toeic-based quiz untuk mendukung pembelajaran Bahasa Inggris Teknik di politeknik. Aplikasi ini diharapkan akan menjadi media pembelajaran yang dapat meningkatkan speaking, writing, dan listening skill mahasiswa dalam berkomunikasi menggunakan istilah-istilah di bidang Teknik. Materi Bahasa Inggris Teknik dalam aplikasi ini juga didukung oleh visual gambar yang menarik dan menunya disesuaikan dengan setiap Program Studi. Sehingga, dengan aplikasi ini mahasiswa diarahkan agar lebih termotivasi dalam belajar Bahasa Inggris diluar kelas seperti halnya ketertarikan mereka terhadap permainan atau games online. Penelitian ini merupakan penelitian pengembangan yaitu mengembangkan aplikasi 'Technical English' berbasis Android untuk memudahkan mahasiswa dalam belajar Bahasa Inggris Teknik. Software yang digunakan penelitian ini adalah React Native dan metode pengembangannya menggunakan model System Development Life Cycle (SDLC) dengan pendekatan Waterfall.
\end{abstract}

\section{Kata kunci: Aplikasi Android, Smart Technical English, Keahlian Bahasa Inggris}

\section{LATAR BELAKANG}

Pada dasarnya lulusan perguruan tinggi vokasi dituntut untuk siap kerja dan siap bersaing di era globalisasi saat ini. Hadirnya Masyarakat Ekonomi Asia (Asian Economic Community) dan industry 4.0 membuat dunia industri semakin selektif dalam memilih SDM yang sesuai dan unggul. Disinilah lulusan politeknik perlu untuk mencari celah keunggulan tidak hanya dalam kompetensi bidang teknik tetapi juga komunikasi dan bahasa asing, yaitu Bahasa Inggris agar mampu bersaing kompetitif dengan para pekerja asing. Banyak faktor yang mempengaruhi keberhasilan mahasiswa dalam menguasai Bahasa Inggris diantaranya adalah strategi pengajaran yang tepat dan menuntut banyak latihan dan praktek, serta media pembelajaran yang menarik yang dapat memotivasi dan memicu mahasiswa untuk belajar. [1]

Beberapa permasalahan yang ditemukan pada mahasiswa di PPNS adalah Speaking skill yang kurang, Writing skill yang masih standar karena penguasaan kosakata yang terbatas. Mahasiswa juga kurang termotivasi untuk belajar Bahasa Inggris karena beberapa alasan, diantaranya adalah mereka kurang termotivasi karena Bahasa Inggris bukan Matakuliah Inti pada studi mereka, dan terbatasnya waktu untuk belajar di luar kelas karena jadwal perkuliahan yang sangat padat. Hal ini menyebabkan kurangnya penguasaan kosakata yang juga berakibat pada kurang terampilnya dalam berbicara dan menulis menggunakan Bahasa Inggris Teknik. 
Disisi lain, dalam era globalisasi dimana teknologi berkembang dari digital ke internet, kesempatan inovasi dalam pengembangan teknologi sebagai sarana prasarana dalam proses pembelajaran, semakin terbuka luas. Perkembangan teknologi kini bisa diarahkan sebagai sarana dalam proses pembelajaran yang disebut mobile learning atau m-learning.

Mahasiswa dapat menggunakan gadget yang mereka memiliki seperti ponsel dan tablet sebagai perangkat pembelajaran yang membuat $m$-learning menjadi solusi baru dalam kegiatan pembelajaran. Kini telah banyak perangkat mobile smartphone menggunakan sistem operasi Android yang open source. Android memungkinkan pengguna untuk berkomunikasi dengan siapa pun setiap saat dan tempat hampir seketika melampaui banyak hambatan. [5]

Saat ini mayoritas mahasiswa memiliki handphone Android dimana mereka dapat mengunduh berbagai macam aplikasi menarik dan bermanfaat. Sebagian besar bahkan telah memanfaatkan aplikasi yang mereka unduh dari PlayStore untuk mempermudah aktivitas belajar mereka seperti kalkulator, kamus Bahasa Inggris, dan dokumen scanner. Melihat perkembangan teknologi tersebut sangat mungkin untuk mengembangkan aplikasi berbasis Android yang dapat dengan mudah diunduh oleh mahasiswa untuk mempermudah belajar Bahasa Inggris dimanapun dan kapanpun mereka mau. Saat ini telah ada beberapa aplikasi Android seperti DuoLingo, Engineering Dictionary, dan Learn English Conversation yang dapat diunduh untuk memudahkan belajar Bahasa Inggris. Namun, belum ada satu aplikasi yang tepat yang menggabungkan antara kosakata Bahasa Inggris Teknik dengan latihan menulis dan conversation Bahasa Inggris untuk Engineers.

Bertolak dari masalah dan fenomena tersebut, peneliti ingin mengembangkan aplikasi Smart Technical English berbasis Android yang layak digunakan untuk mendukung pembelajaran Bahasa Inggris Teknik di politeknik. Aplikasi ini diharapkan akan menjadi media pembelajaran yang dapat meningkatkan speaking, writing, dan listening skill siswa dalam berkomunikasi menggunakan istilah-istilah di bidang Teknik. Materi Bahasa Inggris Teknik dalam aplikasi ini juga didukung oleh visual gambar yang menarik dan menunya disesuaikan dengan setiap Program Studi yang ada. Dengan aplikasi ini mahasiswa diarahkan agar lebih termotivasi dalam belajar
Bahasa Inggris diluar kelas seperti halnya ketertarikan mereka terhadap permainan atau games online.

\section{TINJAUAN PUSTAKA \\ A. Mobile Learning}

Istilah Mobile Learning mengacu kepada penggunaan perangkat/ perangkat teknologi informasi (TI) seperti smartphone, telepon genggam, laptop dan tablet PC, oleh peserta didik dalam mengakses informasi dan materi pembelajaran dimana saja dan kapan saja. [8] Mobile Learning merupakan bagian dari electronic learning (e-Learning) sehingga, dengan sendirinya, juga merupakan bagian dari distance learning (d-Learning).

Beberapa kemampuan penting yang harus disediakan oleh perangkat pembelajaran Mobile Learning adalah adanya kemampuan untuk terkoneksi ke peralatan lain (terutama komputer), kemampuan menyajikan informasi pembelajaran dan kemampuan untuk merealisasikan komunikasi bilateral antara pengajar dan pembelajar. Mobile Learning adalah pembelajaran yang unik karena pembelajar dapat mengakses materi pembelajaran, arahan dan aplikasi yang berkaitan dengan pembelajaran, kapan-pun dan dimana-pun. Hal ini akan meningkatkan perhatian pada materi pembelajaran, membuat pembelajaran menjadi pervasif, dan dapat mendorong motivasi pembelajar kepada pembelajaran sepanjang hayat (lifelong learning). Selain itu, dibandingkan pembelajaran konvensional, Mobile Learning memungkinkan adanya lebih banyak kesempatan untuk kolaborasi secara ad hoc dan berinteraksi secara informal diantara pembelajar. [5]

Adapun beberapa kelebihan Mobile Learning dibandingkan dengan pembelajaran lain adalah:

1. Dapat digunakan dimana-pun pada waktu kapan-pun, kebanyakan perangkat bergerak memiliki harga yang relatif lebih murah dibanding harga PC desktop

2. Ukuran perangkat yang kecil dan ringan daripada PC desktop

3. Dapat mengikutsertakan lebih banyak pembelajar karena mobile Learning memanfaatkan teknologi yang biasa digunakan dalam kehidupan sehari-hari.

4. Dalam pembelajaran e-Learning, independensi waktu dan tempat menjadi faktor penting yang sering ditekankan. Namun, dalam e-Learningtradisional 
kebutuhan minimum tetap sebuah PC yang memiliki konsekuensi bahwa independensi waktu dan tempat tidak sepenuhnya terpenuhi. Independensi ini masih belum dapat dipenuhi dengan penggunaan notebook(komputer portabel), karena independensi waktu dan tempat yang sesungguhnya berarti seseorang dapat belajar dimana-pun kapan-pun dia membutuhkan akses pada materi pembelajaran. [7]

\section{B. Aplikasi}

Aplikasi adalah kumpulan program yang dibuat untuk melakukan pekerjaan-pekerjaan tertentu (khusus) [4]. Beberapa aplikasi yang digabung bersama menjadi suatu paket kadang disebut sebagai suatu paket (application suite) contohnya adalah Microsoft Office dan Open Office.org, yang menggabungkan suatu aplikasi pengolah kata, lembar kerja, dll. Aplikasiaplikasi dalam suatu paket biasanya memiliki antarmuka pengguna yang memiliki kesamaan sehingga memudahkan pengguna untuk mempelajari dan menggunakan tiap aplikasi. Sering kali, mereka memiliki kemampuan untuk saling berinteraksi satu sama lain sehingga menguntungkan pengguna contohnya, suatu lembar kerja dapat dibenamkan dalam suatu dokumen pengolah kata walaupun dibuat pada aplikasi lembar kerja yang terpisah.

\section{Android}

Android adalah sistem operasi untuk perangkat mobile yang pengembangannya dipimpin oleh Google [6]. Android menyediakan platform yang terbuka bagi para pengembang untuk menciptakan aplikasi mereka. Saat ini sudah banyak vendorvendor smartphone yang

memproduksi smartphone berbasis android seperi Samsung, Sony, LG, dan lain-lain. Tidak hanya menjadi sistem operasi di smartphone, saat ini android menjadi pesaing utama dari Apple pada sistem operasi Tablet dan PC.

Android memiliki banyak kelebihankelebihan, namun juga seperti sistem operasi yang lain android juga memiliki kelemahankelemahan sendiri. Berikut kelebihan dan kekurangan dari sistem operasi android:

Kelebihan sistem operasi Android:

1. Android bersifat terbuka kerena berbasis linux yang memang open sourcesehingga bisa dikembangkan oleh siapa saja.

2. Kemudahan mengakses Android Market Application
3. Mendukung semua layanan google, sistem operasi android mendukung semua layanan dari google muli dari gmail sampai google reader.

4. Dapat melakukan modifikasi pada ROM dan tidak membahayakan perangkat.

5. Fasilitas penuh USB, dapat mengganti baterai, mass storage, disk drive, dan usb thatering.

Kekurangan sistem operasi android:

1. Sangat memerlukan koneksi internet agar bisa digunakan sesuai dengan kebutuhan pengguna.

2. Perusahaan kadang lambat mengeluarkan pembaharuan android versi terbaru terhadap android versi lama milik pengguna.

3. Sering terdapat iklan pada aplikasi sehingga dapat mengganggu pengguna.

\section{React Native}

React Native adalah framework javascript yang digunakan dalam mengembangkan aplikasi mobile. React Native ditujukan untuk membuat aplikasi mobile yang benar-benar real native dan bukan sekedar membuat aplikasi Web App. Dengan React Native, pengguna aplikasi yang dibuat akan merasakan sensasi aplikasi yang sangat mendekati bahkan tidak dapat dibedakan dengan aplikasi yang asli atau native. Ini dikarena library yang tersedia dalam React Native memang ada native nya, jadi aplikasi yang kita buat langsung terintegrasi dengan aplikasi native atau aplikasi yang sebenarnya. [4]

React Native bekerja dengan dengan menanamkan file Javascript yang sudah dibundle didalam aplikasi, dan menjalankan mereka secara local dari aplikasi yang dibuat. Namun pengguna juga dapat meletakan file Javascript didalam server dan diambil ketika ada koneksi hal ini memungkin kan untuk melakukan update aplikasi secara cepat tanpa melalu proses submit ke Google Playstore atapun iOS Appstore.

Beberapa keunggulan React Native yaitu:

1. Sebagai salah satu alternatif dalam pengembangan aplikasi mobile, react native dapat digunakan untuk mengembangkan aplikasi mobile dalam 2 environment dalam satu kali proses development.

2. Bahasa yang digunakan adalah javascript yang relatif mudah daripada harus belajar Java untuk pengembangan android dan Objective$C$ atau Swift untuk pegembangan iOS. 
3. Truly Native react native sangat mendukung modul native seperti push notifications, deep linking, native UI components dan lain lain.

4. Dokumentasi yang ada sudah lengkap dan juga sudah banyak library-library yang bisa digunakan untuk pengembangan aplikasi sesuai kebutuhan.

\section{METODE}

Penelitian ini merupakan penelitian pengembangan yaitu mengembangkan aplikasi 'Technical English' berbasis Android untuk memudahkan mahasiswa dalam belajar Bahasa Inggris Teknik selain menggunakan handbook sebagai media pembelajaran. Software yang digunakan penelitian ini adalah ReactNative dan metode pengembangannya menggunakan model SDLC. Metode pengembangan yang digunakan dalam pengembangan aplikasi/sistem ini adalah menggunakan model System Development Life Cycle (SDLC) dengan pendekatan Waterfall [3].

1. Requirements \& Analysis: Fase ini meliputi pengumpulan kebutuhan dan menganalisa segala kebutuhan aplikasi/sistem yang akan dikembangkan. [6]

2. Design: Fase ini adalah tindak lanjut dari fase yang sebelumnya. Pada fase ini akan dilakukan pembuatan disain sistem/aplikasi sesuai dengan kebutuhan yang telah teridentifikasi pada fase sebelumnya. Disain yang dibuat meliputi desain sistem/aplikasi dan disain antarmuka (interface).

3. Code: Merupakan fase dimana disain yang telah dirancang akan dikonversi ke dalam bentuk kode program yang dapat dimengerti oleh mesin. Pengkodean dilakukan menggunakan bahasa pemrograman React Native untuk membuat aplikasi.

4. Test: Fase ini meliputi pengujian secara keseluruhan sistem/aplikasi yang telah dibangun. Pengujian dilakukan untuk mengetahui apakah aplikasi/sistem yang dibangun sudah sesuai dengan kebutuhan atau belum. Jika ditemukan kesalahan/tidak sesuai dengan kebutuhan, maka akan dilakukan revisi aplikasi/sistem. Metode pengujian sistem yang digunakan dalam mengembangkan aplikasi ini adalah Black Box Testing Method. Black box testing adalah pengujianprogam yang dilakukan oleh pengembang (programmer) dengan memberikan input tertentu dan melihat hasil yang didapatkan dari input tersebut. Dengan kata lain black box testing terfokus pada fungsionalitas sistem [2].
Metode pengujian Black Box Testing adalah salah satu metode pengujian aplikasi yang mana kita tidak perlu tahu apa yang sesungguhnya terjadi dalam aplikasi atau perangkat lunak [4]. Pengujian Black Box Testing teridiri dari Usability Test dan User Statisfaction yang akan mengidentifikasi kesalahan dalam beberapa kategori, yang mana diantaranya, kesalahan interface, fungsi-fungsi yang salah atau hilang, kesalahan pada struktur data ataupun akses database eksternal, kesalahan inisialisasi serta terminasi dan lainnya [3].

1. Implement/Deploy: Fase ini dilakukan setelah sistem diuji dan hasil pengujiannya sesuai dengan kebutuhan yang telah ditentukan. Pada fase ini, aplikasi 'Technical English' akan diimplementasikan dengan menginstalnya di perangkat android, sedangkan web service akan diimplementasikan di web server yang terdapat di server UPT Komputer PPNS.

2. Maintain: Fase terakhir dari metode SDLC dengan pendekatan Waterfall adalah perawatan aplikasi/sistem. Pada fase ini akan dilakukan perawatan terhadap aplikasi/sistem agar selalu dapat memenuhi kebutuhan penggunanya. Pada fase ini juga dapat dilakukan revisi terhadap aplikasi jika sewaktu-waktu diperlukan. [6]

Meskipun demikian tidak hanya SDLC saja yang diapakai sebagai metode dalam peneliatian ini, tetapi juga menggunakan model prototyping yang digunakan berdasarkan pertimbangan tertentu terkait dengan kelebihannya.

Model prototipe memberikan pendekatan terbaik karena memiliki efisiensi dan kemampuan beradaptasi pada aplikasi "Smart Technical English". [6] Paradigma prototipe dimulai dengan mengumpulkan kebutuhan yang diperlukan yaitu dengan mewawancarai guru/ dosen dan mahasiswa Bahasa Inggris sebagai pengguna untuk menentukan tujuan keseluruhan untuk pembuatan perangkat lunak, mengidentifikasi kebutuhan, dan menentukan beberapa area di mana definisi lebih lanjut diperlukan. Prototipe dievaluasi oleh para guru/ dosen dan mahasiswa dan kemudian digunakan untuk memperbaiki kebutuhan "Smart Technical English" untuk dikembangkan. Iterasi diperlukan karena prototipe dibangun untuk memenuhi kebutuhan guru/ dosen dan mahasiswa bahasa Inggris. 


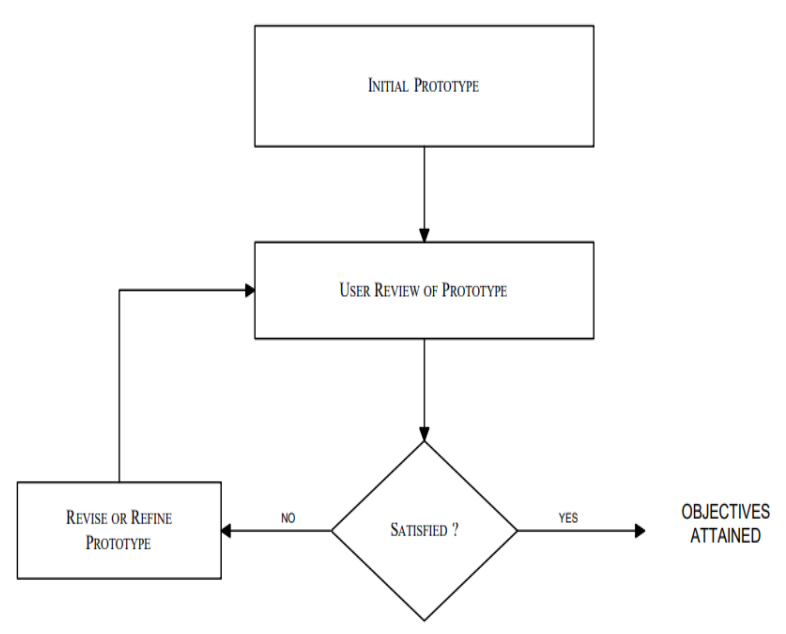

Gambar 1. Proses Prototype Aplikasi "Smart Technical Eglish"

Perangkat lunak yang digunakan untuk mengembangkan aplikasi " Smart Technical Eglish" adalah React Native. React merupakan Java Script open source yang digunakan oleh pengembang untuk membuat antarmuka pengguna web. React Native membantu pengembang untuk membangun aplikasi seluler dengan hanya menggunakan JavaScript. Ini menggunakan desain yang sama seperti React, memungkinkan pengembang untuk menyusun interface pengguna ponsel dengan menggabungkan blok interface pengguna bersama-sama dengan bantuan JavaScript dan React.

\section{Analisis Kebutuhan}

Pada tahap ini, diperoleh informasi mengenai mahasiswa, dosen, dan materi yang diajarkan di setiap program studi. Untuk mendapatkan informasi ini, observasi dan wawancara dilakukan terhadap materi pelajaran dosen dan mahasiswa. Perlu dilakukan analisis kosakata bahasa Inggris yang disajikan dalam aplikasi android Smart Technical English. Beberapa aspek pembelajaran juga direncanakan, mulai dari menentukan Standar Kompetensi, Kompetensi Dasar, indikator dan tujuan pembelajaran.

\section{Pengembangan Prototype}

Ketika analisis kebutuhan materi selesai, langkah selanjutnya adalah mengembangkan prototipe aplikasi Smart Technical English. Perangkat lunak yang digunakan untuk mengembangkan aplikasi " Smart Technical English " adalah React Native. React adalah Java Script open source yang digunakan oleh pengembang untuk membuat interface pengguna web. React Native membantu pengembang untuk membangun aplikasi seluler dengan hanya menggunakan JavaScript. Ini menggunakan desain yang sama seperti React, memungkinkan pengembang untuk menyusun interface pengguna ponsel dengan menggabungkan blok dengan bantuan JavaScript dan React. Produk awal ini kemudian divalidasi oleh pakar media dan pakar materi. Tujuan validasi adalah untuk mendapatkan masukan dan pembenaran dari para ahli terkait dengan validitas materi dan strategi untuk mempresentasikan materi melalui aplikasi.

\section{Uji coba dan Masukan}

Tahap ini adalah fase uji coba aplikasi Smart Technical English. Aplikasi ini diterapkan untuk 200 siswa di 4 program studi yang berbeda, yaitu Teknik Keselamatan, Teknik Kelautan, Teknik Listrik, dan Teknik Pembuatan Kapal. Proses ini juga melibatkan setidaknya 4 dosen bahasa Inggris. Dosen mengirim tanggapan siswa diperoleh melalui wawancara dan kuesioner untuk menentukan kelayakan aplikasi dalam proses pembelajaran bahasa Inggris. Selain itu, feedback juga dapat diperoleh melalui kuesioner dan wawancara, untuk peningkatan aplikasi.

\section{Analisa dan Diskusi}

Analisa dari penelitian ini adalah berupa hasil respon dari questioner yang diberikan kepada 120 mahasiswa dari 12 program studi yang ada di Politeknik Perkapalan Negeri Surabaya. Setiap program studi diwakili oleh 10 mahasiswa yang menggunakan aplikasi 'Smart Technical English' dalam belajar bahasa inggris teknik. Adapun konten dari aplikasi 'Smart Technical English' dibagi menjadi 2 bagian yaitu konten penguasaan kosakata (vocabulary) teknik dan konten tes skill listening dan reading bahasa inggris berupa TOEIC. Berikut visual konten dari aplikasi 'Smart Technical English' 
Oktober 2019 Jurnal Pendidikan Bahasa dan Sastra Indonesia

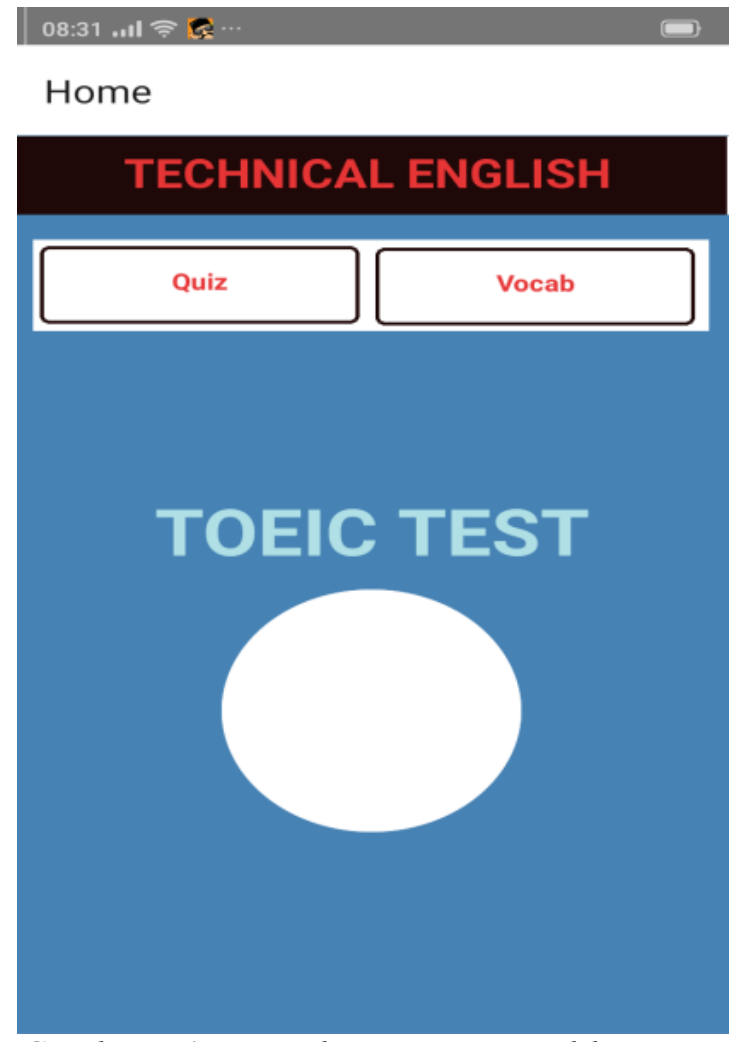

Gambar 1. Display utama aplikasi 'smart technical english'

Pada gambar 1 merupakan bagian display utama aplikasi smart technical English yang menyediakan beberapa pilihan menu diantaranya menu quiz, vocabulary dan toeic test. Untuk penguasaan vocabulary mahasiswa dapat memilih menu vocabulary. Pada menu ini akan menampilkan beberapa gambar yang bertuliskan penjelasan dari gambar tersebut dalam bahasa inggris. Gambar dari menu vocabulary ini adalah sebagai berikut:

\section{Main Engine}
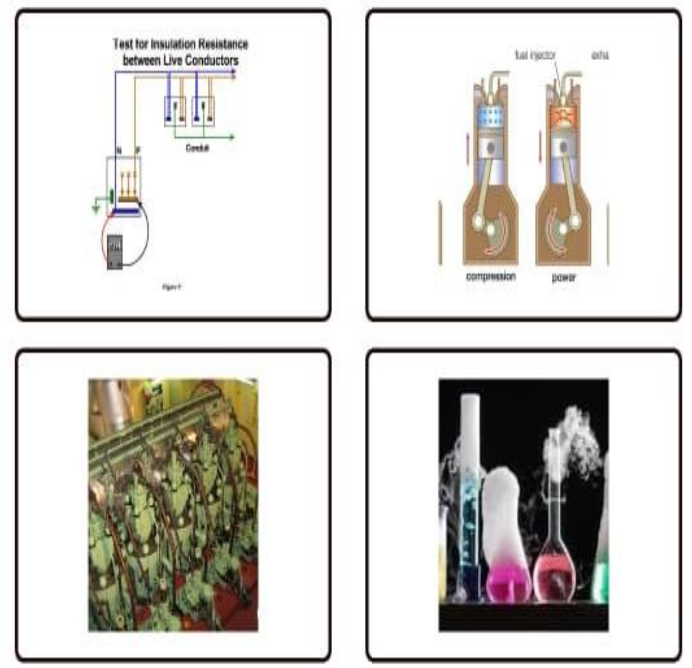

Gambar 2. Menu Vocabulary
Dapat dilihat pada gambar 2 bahwa menu tersebut menampilkan beberapa gambar tentang main engine yang mana mahasiswa dapat memilih gambar dengan cara menyentuh bagian gambar yang diinginkan. Setelah mahasiswa memilih gambar tersebut, menu tersebut akan memberikan definisi gambar dalam bahasa inggris.

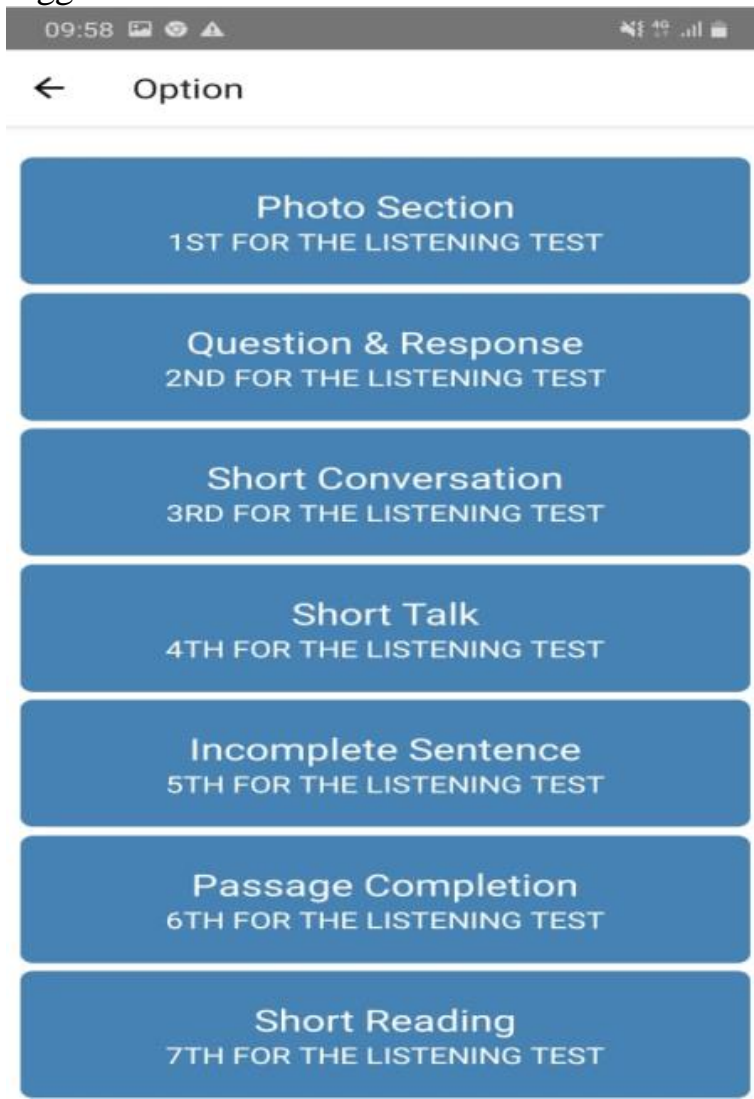

\section{Gambar 3. Menu Tes TOEIC}

Menu tes TOEIC pada gambar 3 merupakan bagian dari praktek listening dan reading yang dikemas dalam bentuk tes yang berupa soal-soal TOEIC. Soal-soal pada tes TOEIC ini memiliki manfaat untuk menilai keahlian listening dan reading bahasa inggris sebagai bahasa komunikasi intenasional. Soalsoal ini dibagi menjadi 7 bagian yaitu bagian photo description, question and response, short conversation, short talk, incomplete sentence, passage completion, and short reading. Sebagai aplikasi berbasis android, pada tampilan tersebut mahasiswa dapat memilih salah satu bagian yang diinginkan. Misalkan pada pilihan bagian photo description pada gambar 4 dan 5 merupakan bagian soal listening yang menampilkan intruksi dalam menjawab soal dan juga menampilkan photo soal. Dengan demikian mahasiswa hanya mendengarkan statement dan mencocokannya dengan gambar yang tersedia.

\section{UTM JOURNALS}




\section{BAHASA INGGRIS MAHASISWA VOKASI}

\section{$09: 58 \odot \div$ \\ कis 49 and}

\section{$\leftarrow \quad$ Photo Section}

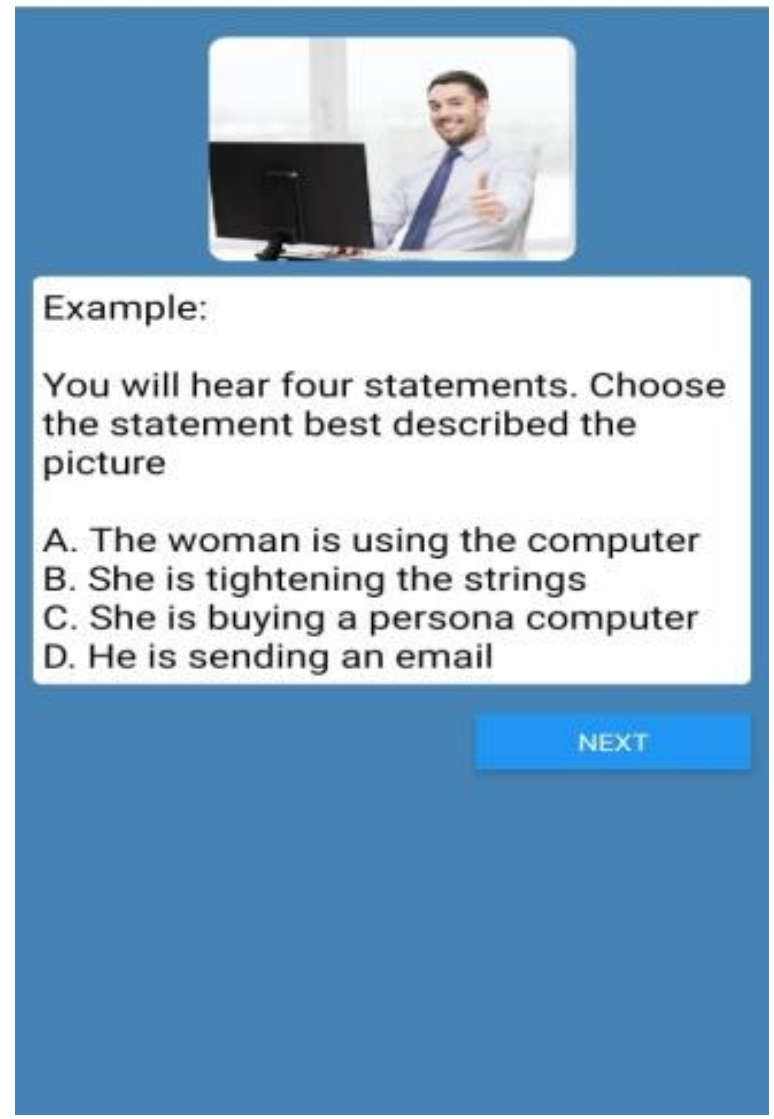

Gambar 4 intruksi photo section

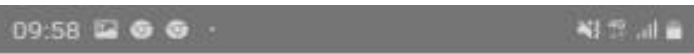

\section{$\leftarrow \quad$ Photo Section}

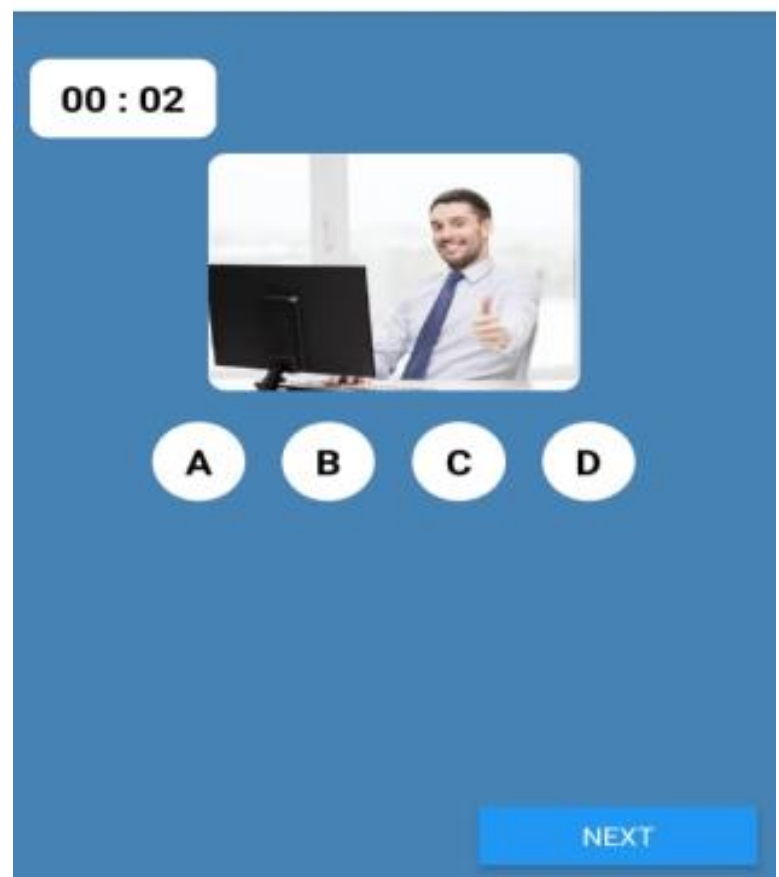

Gambar 5 soal photo section

Setelah mahasiswa melakukan tes listening pada sesi photo description mahasiswa dapat melanjutkan tes pada bagian yang lain. Selain itu pada tes ini mahasiswa juga dapat memeriksa jawaban secara langsung.

Adapun analisa dari penggunaan aplikasi 'smart technical english' tersebut dapat dilihat dari grafik hasil kuesioner yang telah dibagikan mahasiswa sebagai berikut:

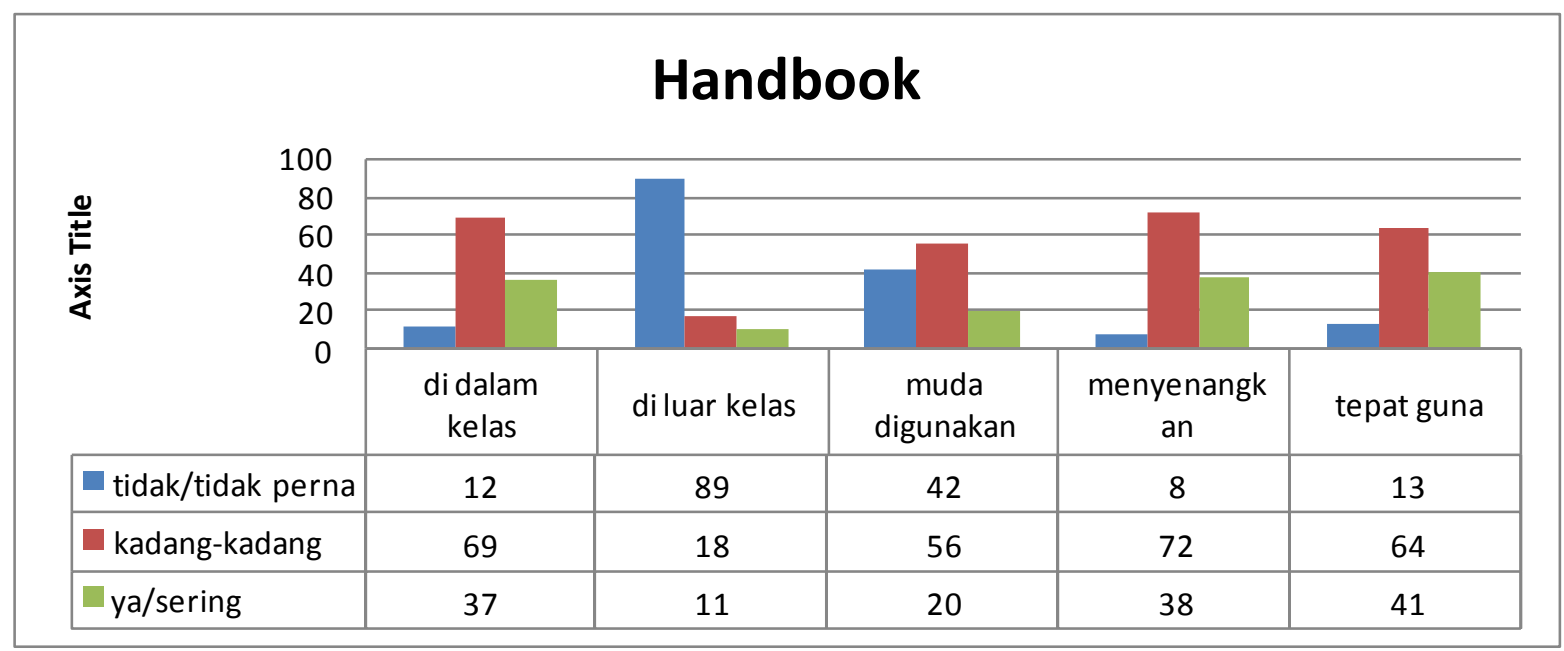

Grafik 1. Penggunaan Handbook untuk pembelajaran bahasa inggris

Pada grafik 1 merupakan hasil bahasa inggris dalam penguasaan kosakata penyebaran kuesioner tentang keefektifan teknik, kuis dan tes toeic. Dari data pada grafik penggunaan handbook sebagai media belajar tersebut menunjukkan bahwa penggunaan 
handbook sebagai media belajar bahasa inggris baik didalam maupun didalam kelas memiliki perbedaan yaitu hampir 50\% mahasiswa yang hanya menggunakan handbook sebagai media pembejaran, sedangkan hampir $75 \%$ mahasiswa tidak perna belajar membuka handbook di luar kelas. Selain itu pembejalaran bahasa inggris teknik dengan menggunakan handbook sebagai media dalam perspektif mahasiswa dianggap kurang efisien dan efektif. Hal ini dikarenakan banyak mahasiswa sekarang yang menggunakan smart phone untuk mengakses pembelajaran berbasis online. Sedangkan pada grafik 2 menjelaskan tingkat keefektifan belajar bahasa inggris mahasiswa dengan menggunakan mobile learning yaitu Smart Technical English. Dari hasil kuesioner pada grafik tersebut dapat dilihat bahwa hampir $75 \%$ mahasiswa tertarik dan termotivasi menggunakan Smart Technical English sebagai media pembelajaran bahasa inggris. Seperti menggunakan aplikasi tersebut tidak hanya dalam kelas saja tetatpi juga menggunakan aplikasi tersebut di luar kelas. Selain itu dengan menggunakan aplikasi ini mahasiswa juga dapat merasakan keefektifan media ini dalam mempelajari kosakata, kuis, dan tes TOEIC dengan tepat.

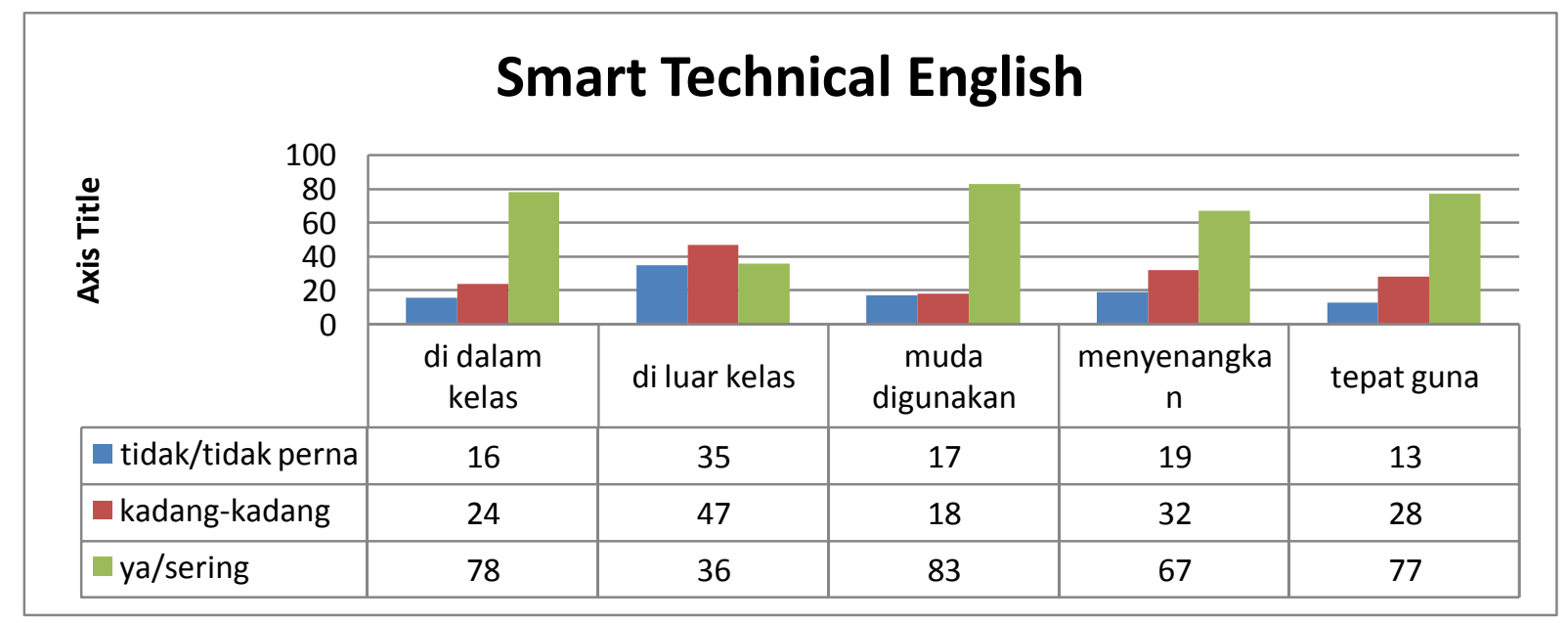

Grafik 2. Penggunaan Smart Technical English untuk pembelajaran Bahasa Inggris

\section{Daftar Pustaka}

Harmer, Jeremy, 2001, The Practice in Language Teaching. $3^{\text {rd }}$ ed. UK: PearsonEducation.

Riduwan. 2009. Belajar Mudah Penelitian untukGuru, Karyawan dan Peneliti Pemula. Bandung : Alfabeta.
Sommerville, Ian. 2003. Software Engineering (Rekayasa Perangkat Lunak). Jakarta: Erlangga.

Utomo, Junaidi., April 2001. Dampak Internet Terhadap Pendidikan : Transformasiatau Evolusi. Seminar Nasional Universitas Atma Jaya Yogyakarta.

Nugroho,A. (2005). "Analisis dan Perancangan Sistem Informasi Berorientasi Objek". Informatika.
Pujadi, Arko. 2007. Faktor-faktor Yang Mempengaruhi Motivasi Belajar Mahasiswa: Studi Kasus Pada Fakultas Ekonomi. Universitas Bunda Mulia, Bussines and Management Jurnal Bunda Mulia: Vol. 3, No. 2 September 2007.

Yusri, I. K., Robert, G., and Carl, M. 2014. Teachers and mobile learning perception: towards a conceptual model of mobile learning for. Prosedia Social and Behavioral Sciences, 176, 425 - 430. 